\title{
Introduction: Why Discuss Nuclear Power Today?
}

Reinhard Haas, Lutz Mez, and Amela Ajanovic ${ }^{l}$

\section{Introduction}

Commercial nuclear power was once depicted as an infinite source of energy to meet growing energy demand. In spite of costs increases, several reactor accidents and remaining challenges regarding radioactive waste, nuclear reactors still play an important role in the energy policy of several countries. However, the future use of nuclear power is a disputed issue in the policy community. There is wide disagreement about the scale of the future use of nuclear power for electricity generation.

While the interest in new nuclear power plants (NPP) in the Western EU-countries and the USA is very modest with few or no plants under construction and planned, there are still talks about new-build in Eastern Europe (Poland, Hungary, Czech Republic, Slovakia, Belorussia, Ukraine), in the Middle East, in Russia, in China and in South-Eastern Asia.

According to the International Atomic Energy Agency (IAEA) 454 NPP are “operational" in 31 countries (as of 11 December 2018). Moreover, 54 reactors were under construction end-2018, with the largest number of new-build in China. The major arguments brought forward in favor of nuclear power are:

1 Reinhard Haas, Technische Universität Wien, Austria, haas@eeg.tuwien.ac.at; Lutz Mez, Freie Universität Berlin, Germany, lutz.mez@fu-berlin.de; Amela Ajanovic, Technische Universität Wien, Austria, ajanovic@eeg.tuwien.ac.at

(C) The Author(s) 2019

R. Haas et al. (Eds.), The Technological and Economic Future of Nuclear Power, Energiepolitik und Klimaschutz. Energy Policy 
1. There are urgent and huge needs for energy especially for electricity;

2. Nuclear energy is necessary to provide base load

3. Nuclear power is indispensable for combatting global warming.

However, an unofficial argument in some countries is to retain (or build up) their military nuclear applications, particularly weapons but also nuclear submarines. Other non-outspoken drivers can be geo-political interests and mere status symbols, as belonging to the rather exclusive club of three dozen countries-15\% of United Nation member states-and mastering what is still considered supreme science remains a goal for some countries or rather regimes.

To understand current and future role of NPP in different countries it is important to learn from the history of nuclear power in electricity generation from a technological and economic point of view. Already in the 1950s, when the economies of many countries (e.g. USA, Europe, Japan, Russia) started to grow fast, and electricity demand grew with the economic development. At that time a desperate need for additional sources for electricity generation beyond limited fossil fuels was seen as essential for continued economic growth. The promises of the nuclear dream emerging in the 1950s were to have cheap electricity in abundance.

In the USA after the early military applications, there was the announcement of the nuclear program "Atoms for Peace" by Eisenhower in 1953. As a consequence, the USA exported reactors to a number of key countries at low prices, launching nuclear ordering. Countries included Germany, France, Spain, Japan, India. The first nuclear plants started operation in the period 1954-1956 in the UK, the Soviet Union and the USA. In the USA "Atoms for Peace" was accompanied by the slogans "too cheap to meter" and the "all-electric home". The idea was that most efforts in households, agriculture and other sectors could be managed by electricity and that electricity could be produced at such low marginal cost that metering would not be justified.

However, as described in this book - given a broad range of subsidies revealed - it is more than doubtful whether such cheap nuclear power has ever existed and prospects of the future competitiveness of nuclear energy appears jeopardized by competition from the surprisingly rapid expansion of renewable energies.

Yet, up to the mid-1970s, nuclear power was booming in many countries and plant by plant was added. Hopes were strong that costs would start coming down with increasing experience.

In the history of nuclear power, there have been three major shocks to the system: The first was the accident in Three Mile Island in the USA in 1979. While reduced economic support slowed construction already before, this accident stopped new 
nuclear power plants constructions in the USA for a long time. The catastrophe beyond the maximum credible accident in Chernobyl in 1986 was a major set-back for the nuclear power industry in Europe. However, the list of large orders has ended already before Chernobyl. The accident in Fukushima in 2011 accelerated Germany's program of phasing-out completely all NPPs by 2022, and profoundly impacted other countries, e.g. Belgium, China, South Korea, Switzerland, Taiwan. Many other accidents with radioactive contamination have happened in the past, however without getting the same attention, e.g. the Kyshtym disaster, and the Windscale fire both in 1957.

Yet the issue of safety is only one amongst a series. Aside from the issue of safety, technical risks, security issues and the unsolved problem of nuclear waste disposal and the economic performance are currently the major barriers for acceptance of NPP. Costs, especially the construction costs of NPP have been increasing since the 1970s and in recent decades they have skyrocketed especially in European countries and North America. Construction time has also become even more subject to overruns. At the same time the costs of renewable energy technologies such as photovoltaics and wind turbines have significantly decreased.

In light of these still falling costs the economic performance of nuclear power in comparison to these renewable technologies is also getting worse. It already has become much harder for nuclear investors to recover money in competitive electricity markets The "base-load" concept has lost its meaning in these markets when low cost renewable sources outperform any thermal power plant. Even the pure operation \& maintenance costs are difficult to recover in today's electricity markets leading to more unfavorable prospects for future nuclear competitiveness.

The increasing construction costs and durations have exacerbated the major problems faced by nuclear power plant vendors. The French vendor AREVA went bankrupt, was bailed out and broken up by the government in 2017. In the same year, the US-based Westinghouse (then owned by Toshiba) declared bankruptcy and, apart from Russian and Chinese vendors, none of the historic vendors has a healthy order book.

Around the turn of the century there were forecasts of a 'nuclear renaissance' or at least of 'rising expectations' based on reactor designs evolved from existing ones, so-called Generation III+. This temporarily revived interest in nuclear power but this new interest has generally not been translated into firm orders. This was sometimes supported by vision of new "cheap and safe" radical new technologies of a so-called generation IV reactors that have been discussed since the early 2000 s. "Small Modular Reactors" (SMRs) are the most recent flavour of the year, but they are still technologically underdeveloped, and financially out of reach. 
The core objective of this book is to provide a comprehensive appraisal of the technical and economic aspects of nuclear power in the next decades. It discusses whether the claimed renaissance of nuclear is really on the horizon or whether the eroding economics as well as technical, legal and industry/vendor issues will continue to close the curtain for this technology. It is organized as follows.

In the next chapter a historical review of the Nuclear Dream is conducted by Rosaria di Nucci from military to early civilian applications. In the following a comprehensive analysis of recent developments and the current state of the world nuclear industry is provided by Mycle Schneider. The collision of atomic and flow renewable power in decarbonization of electricity supply is analyzed by Aviel Verbruggen and Yuliya Yurchenko.

One of the most heavily discussed current issues - costs and economics - are analysed by Reinhard Haas, Steve Thomas and Amela Ajanovic. The major focus of this chapter is on the question, why the real investment costs of NPPs have increased at such a high rate. The specific aspects of one of the most prominent disputed new planned NPP - Hinkley Point C - and its economics compared to renewable energy technologies are investigated by Gustav Resch and Demet Suna in the chapter following.

Another economic issue, which is often ignored, is the cost of nuclear decommissioning. It is treated in two chapters - Wolfgang Irrek analyzes the problem of "financing nuclear decommissioning", and Christian von Hirschhausen, Jan Paul Seidel, and Ben Wealer investigate the decommissioning of NPP, storage of nuclear waste and provide the experiences from Germany, France, and the UK.

Dörte Fouquet reflects on the legacy around the setup and foundation of the EURATOM treaty, the clashing economic nuclear interests of France and the United States on civil use of nuclear power and the respective technologies, the limits and shortcomings of this treaty and its strong support angle at odds with the liberalization of the European energy market.

Tomas Kåberger analyzes the legislation of the economic liability for accidents and back-end costs. David Reinberger, Amela Ajanovic and Reinhard Haas provide a historical overview on nuclear technologies with special focus on the intended new concepts of Generation IV.

The problem of nuclear waste and its long-term disposal is investigated by Gordon MacKerron. As China is currently the most important country world-wide for the development of nuclear power in this book it is treated by M.V. Ramana.

Regarding the large accidents in Chernobyl and Fukushima, three chapters are dedicated to these negative highlights in nuclear history. Nikolaus Müllner analyses the technical versus the human causes about three decades after Chernobyl. The reality after Fukushima in Japan with focus on actual damage to local people 
is investigated by Tadahiro Katsuta. Eri Kanamori and Tomas Kåberger analyze Japan's experience the distribution of the costs of nuclear core melts about six years after Fukushima.

An outlook on the prospects of a future democratic and sustainable electricity generation system is provided in the last chapter by Reinhard Haas and Hans Auer.

Open Access This chapter is licensed under the terms of the Creative Commons Attribution 4.0 International License (http://creativecommons.org/licenses/by/4.0/), which permits use, sharing, adaptation, distribution and reproduction in any medium or format, as long as you give appropriate credit to the original author(s) and the source, provide a link to the Creative Commons license and indicate if changes were made.

The images or other third party material in this chapter are included in the chapter's Creative Commons license, unless indicated otherwise in a credit line to the material. If material is not included in the chapter's Creative Commons license and your intended use is not permitted by statutory regulation or exceeds the permitted use, you will need to obtain permission directly from the copyright holder.

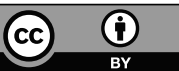

